\title{
THE DETERRENT EFFECT OF FRENCH LIABILITY LAW: THE EXAMPLE OF ABUSIVE CONTRACT TERMS
}

\section{$\underline{\text { Sophie Bienenstock }}$}

Dalloz | «evue d'économie politique »

2019/2 Vol. 129 | pages 205 à 234

ISSN 0373-2630

Article disponible en ligne à l'adresse :

https://www.cairn.info/revue-d-economie-politique-2019-2-page-205.htm

Distribution électronique Cairn.info pour Dalloz.

(C) Dalloz. Tous droits réservés pour tous pays.

La reproduction ou représentation de cet article, notamment par photocopie, n'est autorisée que dans les limites des conditions générales d'utilisation du site ou, le cas échéant, des conditions générales de la licence souscrite par votre établissement. Toute autre reproduction ou représentation, en tout ou partie, sous quelque forme et de quelque manière que ce soit, est interdite sauf accord préalable et écrit de l'éditeur, en dehors des cas prévus par la législation en vigueur en France. Il est précisé que son stockage dans une base de données est également interdit. 


\title{
The Deterrent Effect of French Liability Law: the Example of Abusive Contract Terms
}

\author{
Sophie Bienenstock
}

Most civil and common law regimes rest on the principle of equivalence between the prejudice and the amount of damages allocated to the victim. This rule of compensation is particularly strict in French law and allows for no exception, whether in contract or in tort law.

We question the efficiency of this rule in the specific case of abusive or unfair terms in consumer contracts. French law strictly forbids such terms in any contract signed by a professional party and a consumer. When found in a consumer contract, the forbidden term is removed from the contract, the rest of which remains valid, and the consumer can obtain damages to repair the prejudice in accordance with the rule of equivalence between damages and compensation.

Based on the example of unfair contract terms, the paper raises the issue of the deterrent effect of French liability law. More specifically, we ask the following question: is the rule of equivalence between damages and compensation efficient to prevent unlawful behavior? We show that French consumer law does not efficiently prevent abusive contract terms from being enforced. More generally, we argue that the strict equivalence between damages and compensation does not create efficient incentives for the parties. We argue that the introduction of punitive damages in French law would serve as an efficient incentive device, namely in the presence of lucrative faults.

standard form contracts - unconscionable clauses - punitive damages - consumer policy

\section{L'effet dissuasif du droit de la responsabilité : l'exemple des clauses abusives}

La plupart des régimes de droit civil et de common law reposent sur le principe de stricte égalité entre le préjudice subi et le montant des dommages-intérêts alloués à la victime. Cette règle d'indemnisation, appelée le principe de réparation intégrale du préjudice, est particulièrement stricte en droit français et n'admet que de très rares exceptions.

Cet article soulève la question de l'efficacité de la règle de réparation intégrale dans le cas particulier des clauses abusives dans les contrats de consommation. Les clauses abusives, interdites dans les contrats de consommation, sont réputées non écrites, étant entendu que le reste du contrat demeure valable. Le consommateur peut en outre obtenir des dommages-intérêts en réparation de son préjudice conformément à la règle de réparation intégrale.

\footnotetext{
* Centre d'Économie de la Sorbonne, Université Paris 1 Panthéon-Sorbonne, Paris, France. Mail: sophie.bienenstock@univ-paris1.fr
} 
L'article étudie l'effet dissuasif des règles de responsabilité civile dans le cas particulier des clauses abusives. II s'agit notamment de déterminer si la règle de réparation intégrale permet de dissuader le professionnel d'insérer des clauses abusives dans le contrat. Nous montrons que le droit français ne dissuade pas le rédacteur du contrat de prévoir des clauses abusives. Plus généralement, nous soutenons que le principe de réparation intégrale $n$ 'incite pas au respect de la loi. Nous soutenons que l'introduction de dommages-intérêts punitifs en droit français constituerait un dispositif incitatif efficace, notamment en présence de fautes lucratives.

contrats d'adhésion - clauses abusives - dommages et intérêts punitifs - protection du consommateur

Classification JEL : K12; K42; D21

\section{Introduction}

The French Civil Code rests on the theory of freedom of contract and free will. ${ }^{1}$ According to this paragon, the contract is the result of free negotiations between two autonomous and well informed parties. Subsequently, as Kessler [1943] explains "since a contract is the result of the free bargaining of parties who are brought together by the play of the market and who meet each other on a footing of social and approximate economic equality, there is no danger that freedom of contract will be a threat to the social order as a whole." Alas, most contracts that are signed today depart from this ideal. Agents have neither the time nor the knowledge to negotiate every contact they sign and are reduced to accepting or refusing a standardized contract offered by the other party. The phenomenon of contracts of adhesion, or standard form contracts, is particularly pregnant in the field of consumer relationships.

Consumer contracts are defined in French law as those signed by a professional party on one side, and an individual who is acting outside the scope of an agricultural, industrial, commercial or craft industry concern or that of any other profession, on the other side. ${ }^{2}$ Consumer contracts are drafted by one party (the professional party) and accepted - or rejected - by the other (the consumer). From the consumer's viewpoint, freedom of contract boils down to accepting or refusing an offer. As Kessler [1943] bluntly affirms, "his contractual intention is but a subjection more or less voluntary to terms dictated by the stronger party (...)." Such standard form contracts

1. Article 1102 of the French Civil Code states that "every one is free of contracting or not contracting, of choosing his contractor and the content of the contract in accordance with the limits set by the law" (translation by the author). In its original version, the article provides that: "chacun est libre de contracter ou de ne pas contracter, de choisir son cocontractant et de déterminer le contenu et la forme du contrat dans les limites fixées par la loi."

2. See the preliminary article of the French Consumer Code. 
pave the way to unfair, abusive or one-sided terms: ${ }^{3}$ insofar as the contract is not negotiated, the drafter can insert unfair terms and expect the consumer not to notice or understand all the implications. To avoid such behavior, French law regulates consumer contracts, for instance by imposing upon the professional party information disclosures. Among the very first articles of the French Consumer Code, articles L.111-1 to L.111-8 provide that the professional party has a general information disclosure obligation. Information disclosure raises the acute issue of consumer overwhelming, as highlight Ben-Shahar and Schneider [2014] and Goyder and Brooker [2007].

In this context, a more efficient way of regulating consumer contracts is to forbid certain clauses. Article L.212-1 of the Consumer Code forbids "abusive contract terms", which are defined as those which result in a "significant imbalance" between the rights and obligations of the two parties. Article R.212-1 of the French Consumer Code provides a list of clauses which are prohibited in all types of contracts: for instance clauses with the aim or effect of cancelling or reducing the right to compensation of the consumer in the event of non-fulfilment by the business of any one of its obligations, are prohibited as abusive. Similarly, clauses with the aim, or effect, of reserving the business the right to unilaterally amend the characteristics of the goods to be delivered or the service to be rendered, are prohibited. It is worth noting that according to the French consumer Code, neither the price nor the object of the contract can be qualified as an unfair term. Unfair terms generally refer to secondary aspects of the contract, such as the consequences of a breach of contract; the cases in which parties can terminate the contract early; allowing the professional party to modify the duration of the contract etc.

One could argue that in a competitive framework, firms have incentives to offer efficient contract terms and therefore to avoid abusive or unfair terms. Yet, to the extent that consumers do not read the entire contract, firms only compete regarding the characteristics that consumers do consider in their purchase decision. The non-salient clauses on the contrary are not subject to competition between firms. This mechanism is clearly described by Korobkin [2003]: "while sellers have an economic incentive to provide the efficient level of quality for the attributes buyers consider ("salient" attributes, they have an incentive to make attributes buyers do not consider ("non-salient" attributes) favorable to themselves, as doing so will not affect buyers' purchasing decision." This assumption seems all the more relevant as consumer contracts often imply low financial stakes, which in turn entail low incentives for consumers to engage transaction costs. In practical terms, consumers tend to focus mainly on the price and to neglect other less salient clauses (see Korobkin [2003]). This behavior paves the way to abusive terms regarding other aspects of the contract.

The prohibition of abusive contract terms apply to all consumer contracts as described above. Most consumer contracts imply instantaneous execu-

3. The French Consumer Code uses the expression "clauses abusives", while the English terminology favors "unfair terms". In what follows, we will use the terms "unfair" and "abusive" as synonyms. 
tion on behalf of both parties: for instance in a sales contract the professional party delivers the good while the consumer pays the price agreed upon. Some consumer contracts, such as subscriptions, imply sequential performance and a long-term relation. We believe that the prohibition of unfair contract terms, which applies to all consumer contracts, is the most efficient means to regulate consumer-professional relations, as explained above. Hence, we focus on the regulation of unfair contract terms in order to assess whether French law efficiently deters the professional party from inserting unfair or abusive terms in the contract.

In order to do so, we study the professional party's strategic behavior at the stage of drafting the contract. We consider that the professional party is a rational profit maximizing agent, who faces an alternative: he can either abide by the law, on one side; or insert abusive terms in the contract, on the other side. By comparing the costs and gains ensuing from drafting a legal or an illegal contract, the professional party decides whether or not to insert abusive clauses. Moreover, the drafter anticipates that the consumer has no bargaining power and that the consumer will sign the contract without reading - or understanding - every clause. The consumers' behavior, which consists in not investing in reading and comparing contracts, is rational given the low amounts at stakes. In other words, the consumer will enter into the contract regardless of whether it contains an abusive term. Once the contract has been signed, in the event that it does contain one or several unfair terms, the consumer has the possibility of filing a suit. Finally, we assume that there are no judicial errors of either type.

This framework allows us to tackle the following question: given the prevailing principles in French consumer and contract law, as well as their interpretation by courts, does the drafter of the contract have incentives to respect the prohibition of abusive terms? In other words, this article aims at testing the deterrent effect of French consumer law through the specific example of abusive contract terms. Focusing on the case of abusive terms in consumer law provides a particularly striking example of the shortcomings of French liability law. While the model focuses on the case of unfair contract terms, the conclusions we draw remain relevant in other areas of consumer law and more generally liability law.

We argue that French consumer law does not provide efficient incentives to the drafter of the contract. Several deep-rooted and infrangible legal principles make it difficult to use damages as an incentive device. Mainly, we contend that the rule of strict equivalence between the prejudice and the amount of damages accounts for the lack of deterrent effect of French consumer law and more generally of French liability law. In this regards, French law is not an isolated case. The compensatory nature of damages is common to most legal systems in both common and civil law. However, we show that French law applies this rule with a particular rigor and allows for no exception, while other legal systems do recognize, as a secondary aspect and to various degrees, the punitive nature of damages.

In the specific case of consumer contracts, the lack of deterrent effect is particularly striking. The intuition is quite simple to grasp: firms know that the probability of incurring a lawsuit is low and that the amount of damages will not exceed the prejudice caused to the consumer. Yet, the profit ensuing 
from the abusive term can be quite large, insofar as consumer contracts are signed on a large scale. Hence a rational profit-maximizing firm has incentives to infringe consumer law. This intuition is formalized in a simple model, which consists in applying deterrence theory to the specific case of abusive clauses in consumer contracts.

The model presented in the paper is an illustration of a more general phenomenon, namely the lack of efficiency of the rule of equivalence between damages and the prejudice with regards to deterring illegal behaviors. The model we build and the conclusions we draw are not specific to French law and can easily be transposed to other situations. However, the French legal system provides a compelling example of a situation in which refusing to acknowledge the punitive nature of damages paves the way to intentional torts. The choice to focus on French consumer law is also guided by a specific context: numerous reforms have been proposed and studied but are repeatedly rejected in the name of the rule of full compensation (see below section 5.2.3). The ambition of the article is therefore to point out, in a context where punitive damages are systematically rejected, that they could be useful in some specific areas of law, particularly in consumer law.

In this context, we argue that French law does not prevent a rational agent from committing "lucrative faults", as defined by Starck [1947], to the extent that the profit ensuing from the fault - whether contractual or extracontractual - is more important than the amount of damages the infringer anticipates to pay. An efficient means of preventing such behaviors would be to use liability law as a punishment device, as suggested by Starck [1947], and not as a mere compensation device, as it is the case in French law today. In practical terms, we plead in favor of punitive damages, which could serve as an efficient incentive device in consumer law and beyond. The idea put forward by Starck [1947] is consistent with the current stance in American case law: in the United-States, punitive damages are mainly allowed when the defendant has displayed bad faith or intent to cause harm. The aim of this article is not to argue in favor of systematic punitive damages, but rather to show that in some instances, when the defendant commits a "lucrative fault" or displays bad faith, such damages are relevant. The article argues in favor of punitive damages but does not tackle the issue of how such damages should be implemented. While this is a crucial question, it is outside the scope of this article. It indeed seems sensible to solve first the question of whether punitive damage should be allowed and under what circumstances; and to address next the question of how to regulate them. This latter question is left for further research.

The rest of the article is organized as follows: related literature is presented in the second section. The third section sketches the legal background: it offers a brief overview of French consumer law and focus on some basic principles prevailing in contract law that are relevant to our subject. In the fourth section a simple model is built to capture the drafter's behavior at the pre-contractual stage, in order to assess the deterrent effect of French consumer law with regards to the prohibition of unfair contract terms. Based on the model presented in the previous section, we consider in the fifth section the relevance of punitive damages to increase the efficiency 
of French consumer law. Finally, some concluding remarks are presented in the sixth section.

\section{Related literature}

The article is linked to several fields of literature. First, it is strongly related to the theory of deterrence initially developed by Becker [1968]. While Becker's seminal work has been mostly applied to criminal law, we extend it to consumer law, which has surprisingly been overlooked by the Law and Economics Literature so far. In line with Polinsky and Shavell [1979, 1998, 2007], we argue that the efficiency of a sanction depends on its amount and its probability of occurrence. In their seminal Handbook of Law and Economics, Polinsky and Shavell [2007] explain that "the more likely a party is to escape liability, the higher should be damages when the party is found liable. (...) This possibility may arise because injurers are hard to identify as the sources of harm (...) or because victims do not choose to bring suit (litigation costs may discourage legal action)." 4 We focus on the latter case. We show that in the specific case of abusive terms in consumer contracts, the punishment provided for by French consumer law does not serve as an efficient deterrent. The theory of deterrence involves compelling conclusions in the case of standard form contracts and pleads in favor of punitive damages.

To the extent that punitive damages can lead to a system in which the amount awarded to the plaintiff differs from the payment by the defendant, the article is also related to the literature on decoupled liability. Polinsky and Che [1991] study liability decoupling as a means of constraining frivolous suits while increasing the incentive of the defendant to exercise care. According to the authors, the optimal payment is as high as possible, in order maintain the injurer's care at a high level, and to keep litigation costs low. In line with Polinsky and Che [1991], we argue that decoupling liability can increase the efficiency of the legal rule. In contrast to Polinsky and Che [1991], we focus only on one of the virtues of decoupled liability: our concern is the impact of decoupled liability on the defendant's incentive to respect the law, rather than on the plaintiff's incentive to engage in frivolous suits. The reason is that in our framework, consumers only engage in suits when there is an abusive clause. In other words, we do not tackle the issue of frivolous suits, but rather focus on the defendant's behavior.

More generally, the literature on decoupled liability has tackled related yet different issues. Lewis and Sappington [1999] focus on the particular case of a producer who has insufficient wealth to compensate victims for the damages that can arise from his activities. They conclude that decoupling liability and damages leads to greater social welfare than strict equivalence

4. Polinsky and Shavell [2007], page 166. 
between the prejudice and the damage. We come to the same conclusion, but the context and the question tackled are very different. In the situation we study, the firm could easily compensate the victims for the harm, since small damages are at stake. The issue is not that firms have insufficient resources but rather that consumers have insufficient incentives to go to trial.

Innes [1999] focuses on a related issue. In an article entitled "Optimal Liability With Stochastic Harms, Judgment-Proof Injurers, and Asymmetric Information", Innes [1999] studies the case of decoupling in which the injurer's assets are insufficient to cover for the harm caused to the victim. The case we study is very different from the one mentioned in Innes [1999]. The latter focuses on "particularly harmful accidents", that is to say important damages such as product failures or industrial disasters. The problem studied by Innes [1999] differs from ours in at least two ways: first, the prejudice caused is important and exceeds the assets of the injurer. On the contrary, we study small damages, which are key characteristics of consumer contracts (as emphasized in the introduction above). Second, under the assumptions described in Innes [1999], the injurer does not deliberately cause damages to the victim. In our model, the firm carries out a cost/benefit analysis and rationally decides to violate the law, which results in damages for the customers.

Secondly, the paper also builds on the literature dedicated to contracts of adhesion. One salient feature of consumer contracts is indeed that they are drafted by one party - the professional - while the other party - the consumer - has no bargaining power. The consumer can only accept or reject the contract that is offered to him. As highlighted by Kessler [1943], in a context where freedom of contract is only a decoy, the rules of civil law, which rely on the fundamental assumption that each party gives a free and enlightened consent before entering into a contract, are no longer relevant. More recently, Korobkin [2003] also insisted on the particularity of the consumer-professional interactions: the author highlights that the firm enjoys a specific power insofar as it is a repeat-player. Given these characteristics, consumer contracts provide an enlightening and blatant example to study the deterrent effect of liability law.

Finally, the paper is also related to the legal literature concerned with the nature and the role of civil liability. Traditionally, liability is conceived in France as a mere means of compensation. For instance Le Tourneau [2011] defines civil liability as "the obligation to repair a damage caused to a third party because of an act contrary to the legal order". 5 In the same line of thought, Cadiet [2000] argues that "in the system stemming from the Civil Code, liability and compensation perfectly coincide". 6 Yet, this traditional view which constrains civil liability to compensation has progressively been questioned and contested. As thoroughly explained by Sintez [2014], an increasing number of scholars acknowledge the deterrent and normative role of civil liability. For instance Tunc [1975] contends that "liability contributes to preventing anti-social behavior by exerting against them an intimi-

5. Translation by the author.

6. Translation by the author. 
dation effect, or as we would say today, a deterrent effect".7 Similarly, Malaurie [2004] puts forward the "prophylactic" role of civil liability. We take part in this vast debate and argue that liability should no longer be conceived only as a mere means of compensation. The preventive role of civil liability, which has been neglected and denied by French scholars, deserves to be acknowledged.

\section{The legal framework}

The legal regime of abusive contract terms is defined in the French Consumer Code (section 3.1). The implementation of the regime rests on a cooperation between the the judicial power and the Commission des Clauses Abusives (section 3.2). We will briefly mention their respective roles in the struggle against unfair contract terms. We will then present succinctly the rules regarding the allocation of damages in French law (section 3.3).

\subsection{The legal regime of abusive contract terms}

The French legislator's first intervention concerning unfair terms in consumer contracts dates back to 1978. In its original version, the Scrivener law provided that any contract term resulting in an "excessive advantage" for the professional party should be regarded as abusive, and would therefore be prohibited. The criterion of "abuse" thus relied on the existence of an "excessive advantage". Under the influence of European Law, however, this criterion underwent fundamental change. The European Directive of April $5^{\text {th }}$ 1993 about unfair terms in consumer contracts provides that "a contractual term which has not been individually negotiated shall be regarded as unfair if, contrary to the requirement of good faith, it causes a significant imbalance in the parties' rights and obligations arising under the contract, to the detriment of the consumer. ${ }^{\text {" }}$ It is worth noting that the criteria of abuse consists in a "significant imbalance" between the rights and obligations of the two parties. The criterion of a "significant imbalance" now prevails in the French Consumer Code, as provided for by article L.212-1.

The French Consumer Code also mentions the consequences of an unfair term in a consumer contract. The rule is here quite simple: all abusive terms are considered never to have been written; the judge must simply act as is if the unfair term had not existed and, if necessary, fill in the subsequent gap. If the contract can remain valid despite the suppression of the abusive term, it shall be enforced. In practice, it often happens that the consumer brings a case to court because the disputed clause has already caused him

7. Translation by the author.

8. Council Directive 93/13/EEC of 5 April 1993 on unfair terms in consumer contracts. 
a prejudice. In such a situation, considering that the clause has never been written does not by itself compensate for the damage caused to the consumer. It is necessary to also allow damages equivalent to the prejudice caused by the illegal clause. Think for example of a clause which allows the professional party to unilaterally decide whether the good delivered meets the contractual requirements (such a clause is considered abusive under article R.212-1 of the French Consumer Code). The consumer undergoes a damage due to the fact that the professional party has delivered a good different from the one the parties had agreed upon. Judging that the clause is void and enforcing the contract without the clause seems impossible since the damage has already been realized and needs to be compensated for. In situations when the contract can be enforced without the clause, the prejudice still calls for compensation. Think for instance of a clause allowing the professional party to terminate the contract early, without offering the same right to the consumer (such clauses are relevant in the case of long-term contracts such as subscriptions). If the professional party does terminate the contract early, the consumer suffers a prejudice due to the fact that he either has to look for a new provider, or that he no longer has access to the service. Considering ex post that the clause is void is not sufficient to compensate for the damage caused to the consumer. The previous examples show that it is not always possible to enforce the contract without the disputed clause; and that even when the contract remains enforceable, the clause might have caused a prejudice to the consumer. Hence, we consider in what follows that an abusive contact term causes a prejudice to the consumer.

It is worth highlighting that a judicial procedure is always necessary to avoid the abusive term from being enforced or to obtain damages. In other words, each and every consumer who considers a term to be unfair will have to bring a civil action against the other party. To the extent that class actions are not allowed in French consumer law, this mechanism entails numerous trials, subsequent judicial fees and significant social costs, which could be avoided with more efficient procedures. If the consumer files a claim before court, the professional party can be condemned to repair the prejudice caused to the consumer. Moreover, according to article L.241-2 of the Consumer Code, a "civil penalty" paid to the state can be added to the amount of compensation. However, in practice, such civil penalties are extremely rare. In addition, the amount of the civil penalty is limited to 3000 euros for a natural person and to 15000 euros for a legal entity. We argue below that providing such a maximum amount can reduce the deterrent effect of the legal rule.

\subsection{Who decides that a term is unfair?}

In its original version, the Scrivener law provided that only the government could decide upon the abusive nature of a contract term. More precisely, a decree issued by the Conseil d'État was necessary to declare a certain type of clause unfair. The courts then had to follow the decree, and had no leeway as far as the qualification of the clause was concerned. Only 
one decree was passed in 1978 on the ground of the Scrivener law. Very quickly, this provision proved to be an inadequate reply to the problem of unfair terms in consumer contracts.

In response to the government's inertia, the French Supreme Court ruled, in a very noteworthy decision of May $14^{\text {th }} 1991^{9}$, that the qualification of a clause as "abusive" devolved upon the courts. In other words, this ruling gave French judges an autonomous power to declare any contract term abusive with regards to the Consumer Code. This system had essentially one drawback: the legal uncertainty that weighed on the drafter of the contract. Indeed, the drafter had no means of knowing in advance which contract terms would be considered as unfair. To overcome this deficiency, the legislator introduced in the Consumer Code two lists of abusive terms. The Loi de Modernisation de l'Économie 10 inserted a black and a gray list. The former contains terms that are considered to be unfair under all circumstances. The later contains terms that are only presumed to be unfair. In this case, the professional party can provide proof that the term should not be considered unfair.

In a sense, the gray list involves a shift of the burden of proof. In civil law, the burden of proof usually weighs on the plaintiff. This rule is often illustrated through the maxim "actori incumbit probatio"11 and is mentioned at article 1315 of the French Civil Code. ${ }^{12}$ Hence, by providing that the defendant (the professional party) must prove that the clause in not abusive, the Consumer Code operates a shift of the burden of proof. Subsequently, a consumer who brings a claim is presumed to be correct, until the professional party proves otherwise. In practical terms, the professional party must prove that the disputed clause does not cause a significant imbalance between the rights and obligations of the parties. The first consequence is that the costs incurred by the consumer are lower than if he had to bear the burden of proof. Moreover, it is more efficient that the burden rests on the party who detains more information, as show Fluet and Demougin [2008]. In the case of consumer contracts, the professional party naturally detains more information. Second, the presumption serves as an ex ante incentive for the professional party to respect the legal rule. As highlight Bernardo et al. [2000], legal presumptions can serve as ex ante incentives to comply with the law, to the extent that they increase the expected cost of violating the rule. Finally, a shift of the burden of proof also results in more frequent type 1 errors (the drafter of the contract will be held liable although the clause is not abusive) than type 2 errors (the drafter is not liable in the presence of an abusive clause). As explain Fluet and Demougin [2005], defining the standard and the burden of proof affects the probability of type 1 and type 2 errors. This last phenomenon is not captured in the model presented below since we do not allow either type of errors. Yet, it is worth noting that, for the

9. Cass. 1er civ., 14 mai 1991, Dalloz. 1991, p. 449.

10. Law $n^{\circ} 2008-776$, August $4^{\text {th }} 2008$, known as Law of modernization of the Economy.

11. The burden of proof weighs on the plaintiff.

12. According to this article "A person who demands the performance of an obligation must prove it. Reciprocally, a person who claims to be released from an obligation must prove the payment or the fact that caused the extinction of his obligation".

REP 129 (2) mars-avril 2019 
several reasons mentioned above, the shift of the burden is favorable to consumers.

This list system seems at first glance to be quite satisfactory, as it reconciles the two constraints of legal certainty on the one hand, and efficiency on the other hand. However, it does have one main drawback: the dozen of terms listed by the Consumer Code only includes a small fraction of the unfair terms most frequently encountered in consumer contracts. Many more types of contentious terms are likely to be found. In this event, the judge has to decide whether the term meets the criteria of article L.212-1 of the French Consumer Code. The Commission des Clauses Abusives precisely aims at filling this void by giving a non-mandatory guide to the courts and contracting parties.

The Commission of Abusive Contract Terms is an agency placed under the authority of the Ministry of Consumer Relation. The Commission was created by the aforementioned Scrivener law of January 1978, and is devoted to drafting non-judicial and non-mandatory recommendations about unfair terms in consumer contracts. Article L.822-4 of the Consumer Code states that the Commission is in charge of studying standardized contracts offered to consumers and to detect whether some terms might be considered unfair. The Commission's recommendations are not mandatory, insofar as that they do not bind the courts. However, their impact on the content of consumer contracts should not be under-estimated. Although they are not a "formal source of law" they are undeniably a "true source of law" (Leveneur [2009]). At least two reasons account for the importance of the Commission's recommendations: not only do they provide a useful guide for the courts facing a question relevant to unfair contract terms, but they also allow the parties (mainly the drafting party) to form legitimate expectations.

We now have a relatively complete overview of French consumer law, as far as the prohibition of unfair terms is concerned. In order to complete this picture, we must mention briefly a few fundamental rules of French contract law, to the extent that they are applied in the field of consumer law.

\subsection{The allocation of damages in contract law: the principle of full compensation}

The rule of full compensation prevails in French law (section 3.3.1), although it rests on no solid foundation (section 3.3.2).

\subsubsection{The rule of full compensation: its significance and implications}

The prevailing principle in French law concerning the allocation of damages is known as "principe de réparation intégrale du préjudice", which one could translate into "the rule of full compensation". This rule applies to 
contractual as well as tort law and is considered to be an intangible principle at the basis of civil liability. By way of derogation to this rule, article L.241-2 of the French Consumer Code provides that the judge can pronounce an additional sanction, in the form of a "civil penalty". This mechanism is theoretically close to punitive damages but has in practice very little effect. First, the amount of the penalty is limited to 3.000 euros and 15.000 euros respectively for a natural and a legal person. The amounts are clearly too low to have a strong deterrent effect with regards to the potential gains ensuing from a lucrative fault. Second, this article is extremely scarcely used by judges. In the following section, we build a model that takes into consideration the possible allocation of a civil penalty.

The particularity of the French legal system does not rest in the principle of full compensation but rather in the strictness with which it is applied. The only exception provided for in the French civil Code is the above mentioned "civil penalty", which is never actually used by courts. As point out Viney and Jourdain [2001] in their seminal handbook on civil liability, the denomination "principe de réparation intégrale" is actually quite deceiving: the term of "equivalence" between prejudice and compensation would be more appropriate, since the rule entails that the amount allocated to the victim should be strictly equal to the prejudice. The underlying idea is that a claimant should never be enriched by a judicial procedure. The whole prejudice should be compensated, neither less nor more.

The rule of full compensation, which has no clear textual ground, is applied with the same rigor in tort and contract law. The rule is essentially case-law based and is regularly reminded by the French supreme court through the exact same phrase: "The characteristic of civil liability is to restore as precisely as possible the balance destroyed by the damage and to replace the victim in the situation that would have been his, had the damage not occured".13 This rule has been regularly restated in the exact same terms by the French Supreme Court during the past sixty years. ${ }^{14}$ The French Supreme Court also regularly reasserts that "damages allocated to the victim should repair the prejudice, without leading to a loss or a profit." 15

The statement of the French Supreme Court implies that civil liability is conceived as a mere means of compensation, as opposed to a punishment or incentive device. This stance is well anchored in French law, as explains Sintez [2014]. Civil liability is envisioned as a means of compensation only. For instance, Le Tourneau [2011] defines civil liability as "the obligation to repair a damage." This approach leaves no room for the deterrent effect of civil liability, which is constrained to compensation. According to this view-

13. Translation by the author. The original phrase can be found the decision Cass. Civ. 2e, 23 november 1966 and is as follows: "le propre de la responsabilité civile est de rétablir aussi exactement possible l'équilibre détruit par le dommage et de replacer la victime dans la situation où elle se serait trouvée si l'acte dommageable n'avait pas eu lieu."

14. For a recent example, see Cass. com. 25 january 2017, n 15-16060.

15. Translation by the author of the decision $n$ 01-00.200, cour de cassation, Deuxième chambre civile, 23 janvier 2003. The French version is as follows: "les dommages-intérêts alloués à une victime doivent réparer le préjudice subi sans qu'il en résulte pour elle ni perte ni profit." This rule is also mentioned in the above mentioned decision of 25 january, 2017 (Cass. com. 25 january 2017, n 15-16060). 
point, civil liability and compensation should "perfectly coincide", as writes Cadiet [2000]. In other words, where there is no compensation, there should be no liability. Once again, this stance is not compatible with the idea that liability could serve other purposes, such as punishment or deterrence. While the opinion that civil liability should only serve for compensation and not as an incentive device is widespread, it rests on no textual foundation.

\subsubsection{The absence of textual foundation}

In contract law, the rule of full compensation implicitly stems from article 1231-3 of the French Civil Code. According to this article, any prejudice suffered by a contracting party is settled by expectation damages, which aim at putting the non-breaching party in the position that would have been his, had the contract been fulfilled. More precisely, article 1231-3 of the French Civil Code provides that the debtor only has to pay for the damages that were expected or that could have been expected at the time the parties entered into the contract.

In tort law (as opposed to contract law) compensatory damages are allowed in order to compensate the claimant for any kind of injury, loss, or prejudice resulting from the defendant's breach of duty. As in contract law, the claimant's prejudice should be repaired, but in no event should he be enriched by a judicial procedure. Judges usually base their decisions on article 1240 of the French Civil Code (formerly article 1382) which provides that "every act whatever of man that causes damage to another, obliges him by whose fault it occurred to repair it". ${ }^{16}$ One sees at first glance that this article does not entail a strict equivalence between prejudice and compensation. Another interpretation could perfectly be that the amount of damages should be at least equal to the prejudice endured by the victim. Hence, there is no written obstacle to allowing punitive damages in French law.

One can easily grasp the pursuit of equity and social justice that justifies the rule of full compensation. However, our contention is that this principle should be softened under some circumstances, namely in the field of consumer law. To the extent that the rule of full compensation does not rest on any written source, there is no major impediment in the way of bending the rule when necessary. We argue that punitive damages are necessary to deter the professional party from violating the law.

At this stage, and without any formal demonstration, this assertion seems very intuitive. One easily understands that the drafter of a standardized contract has a strong incentive to insert unfair terms, as a result of two combined phenomena: on one hand, the drafter signs many identical contracts which implies that the excepted gains of violating the law can be quite substantial; on the other hand, the drafter rationally expects that the consumer will not to go to court, since judicial fees would largely exceed the compensation he could obtain. It appears that the rule of strict equivalence between the damage and the compensation unambiguously creates wrong

16. Official translation by Legifrance 
incentives for the agents. One could argue that the principle of equivalence between the prejudice and the amount of damages is not specific to French law. In the following section, we show that the particularity of the French rule, compared to other legal systems, lies in its rigor.

\subsection{The specificity of French liability law}

In both the common law and civil law traditions, damages primarily aim to compensate the victim but not to place him in a better position than if the harm had not been caused in the first place. The idea that damages are first and foremost compensatory is widespread throughout European jurisdictions. According to the Rome II Regulation, punitive damages are potentially contrary to the public order: "the application of a provision of the law designated by this Regulation which would have the effect of causing noncompensatory exemplary or punitive damages of an excessive nature to be awarded may, depending on the circumstances of the case and the legal order of the Member State of the court seised, be regarded as being contrary to the public policy (ordre public) of the forum." 17 More generally, damages are conceived throughout Europe as a means of compensation rather than punishment.

The rule prevailing in Great Britain is clearly set forth by the House of Lords in a 1880 decision: the amount of damages "is to be, as far as possible, that amount of money which will put the injured party in the same position he would have been in had he not sustained the wrong". ${ }^{18} \mathrm{How}$ ever, this rule has been nuanced in the famous decision Attorney General vs Blake. In the latter decision, the House of Lords reminds the rule of compensatory damages while paving the way to punitive damages: "leaving aside the anomalous exception of punitive damages, damages are compensatory. "19 In this case Attorney-General v. Blake, the House of Lords granted the state restitutionary damages by requiring the defendant to account for the benefits he had received from his wrongful act.

Although American law is often thought of as very lenient towards punitive damages, they actually remain an exception to the rule: damages are first and mainly compensatory, meaning that they are intended to restore what a plaintiff has lost as a result of a defendant's wrongful conduct. In his "Treatise on the Law of Evidence", Greenleaf [1963] writes "damages are given as a compensation, recompense, or satisfaction to the plaintiff, for an injury actually received by the defendant. They should be precisely commensurate with the injury; neither more nor less". This conception of damages as merely compensatory was prevailing until the first half of the nineteenth century. The idea that damages could serve another purpose progressively irrupted. The statement of Theodore Sedgwick, as early as

\footnotetext{
17. Article 32 or the Regulation (EC) No 864/2007 of the European Parliament and of the Council of 11 July 2007 on the law applicable to non-contractual obligations.

18. See Livingstone v. Rawyards Coal Co (1880) 5 App Cas 25, 39.

19. Attorney-General v. Blake, Jonathan Cape Ltd (Third Party) [2000] E.M.L.R. 949, 962.
} 
1894, is quite striking: "the law permits the jury to give what it terms punitory, vindictive, or exemplary damages; in other words, blends together the interest of society and of the aggrieved individual, and gives damages not only to recompense the sufferer, but to punish the offender. This rule seems settled in England, and in the general jurisprudence of this country. "20

In the United-States, punitive damages are a matter of state law and therefore differ amongst states. Few states do not allow punitive damages at all (Michigan, Nebraska and Washington), while others allow punitive damages only if they are provided for by statute (Louisiana, New Hampshire and South Dakota). Depending on the state, punitive damages are allowed in some specific areas of tort law. In contract law, the rule is that punitive damages cannot be awarded. However, they may be awarded if an independent tort is committed in a contractual setting. ${ }^{21}$ Contrary to a widespread misconception, punitive damages are only awarded in about $5 \%$ of civil cases brought to court. ${ }^{22}$ Finally, punitive damages are often allocated to the victim when the defendant has shown bad faith or has caused the harm voluntarily. ${ }^{23}$

Let us now turn to German law, according to which damages are compensatory in nature. According to article 249(1) of the German Civil Code (BGB, Bürgerliches Gesetzbuch), a person who is liable in damages must primarily restore the injured person or damaged property to the position that would have existed had the wrong not occurred. The prevailing opinion is against punitive damages under German law, namely because such an award could lead to double punishment, which is ruled out by article 103 of the German constitution. Moreover, article 40(3) of the Introductory Act to the Civil Code ("Einführungsgesetzes zum Bürgerlichen Gesetzbuche") provides that "claims governed by the law of another country cannot be raised insofar as they (1) go substantially beyond what is necessary for an adequate compensation of the injured party, (2) obviously serve purposes other than an adequate compensation of the injured party. "It is in the name of this article that the Federal Court of Justice (BGH, Bundesgerichtshof) considered that an American decision awarding punitive damages was contrary to public order and could not be enforced in Germany. ${ }^{24}$

German law is closer to the French legal system, insofar as it is very hostile to punitive damages. Like in France, damages are compensatory in nature and the belief that the injured party should not be enriched as a result of a legal procedure is widespread. Moreover, punitive damages raise constitutional concerns as explained above. However, and in spite of this deep rooted tradition, the idea that punitive damages might be legitimate in some areas of law has gained ground. As early as $1955^{25}$, the German Federal

20. See Sedgwick [1894].

21. See for instance Christie [1991].

22. According to the Bureau of Justice Statistics (available at https://www.bjs.gov/index).

23. For example, in National By-Products Inc. vs Searcy House Moving Co. 731 S.W.2d 194 (1987), the Arkansas Supreme Court found that awarding punitive damages requires evidence that the defendant proceeded intentionally with an unlawful action after knowing that the act was likely to cause injury.

24. BGHZ (4 June 1992 - IX 149/91) 118, 312, 338 ff., 343 ff.

25. BGHZ 18, 149. Decision of July 6th 1955. 
Supreme Court held that damages for pain and suffering were not an ordinary claim for damages: they bear a twofold function and should adequately indemnify the victim for non-pecuniary losses, but also recognize that the tortfeasor owes the victim satisfaction for his fault. The court thus gave up the monistic notion of damages by stating that beyond pure compensation, the victim had a right to satisfaction ("Genugtuung"). As Behr [2005] explains, German law is somewhat "schizophrenic" regarding its behavior towards punitive damages: "On the one hand, since the enactment of the German Civil Code, the general German attitude toward punitive damages is that damages have to be purely compensatory. (...) On the other hand, (...) there is a long and steady line of court decisions that do not fit into this scheme. German courts frequently awarded damages that could not seriously be held to be purely compensatory because they tended to include punitive elements." Even German law, which has been very hostile to punitive damages, now allows them as an exception to the compensatory function of damages.

Conversely, the French legal system does not know of any exceptions to the rule of full compensation. We argue that French civil law is particular not because it is based on the rule of equivalence between the prejudice and compensation, which is common to many jurisdictions, but rather because there is absolutely no exception to that rule, which is excessively strictly applied. Moreover, we show that punitive damages would be particularly relevant in consumer law to fight against abusive contract terms.

\section{The deterrence theory applied to the drafter of consumer contracts}

Recall that consumer contracts are drafted by the professional party, who offers the contract to the consumer. The latter has no bargaining power and can only accept or refuse the offer. Our concern is to assess whether French consumer law efficiently prevents the professional party from inserting unfair terms in the contract. Therefore, the model aims at capturing the professional party's behavior at the stage of drafting the contract. After a presentation of the model (section 4.1), the main results will be exposed (section 4.2).

\subsection{Presentation of the model}

Let us briefly explain the assumptions (section 4.1.1) and then focus on solving the model (section 4.1.2).

\subsubsection{Assumptions}

We focus on the behavior of the drafter of the professional party at the stage of drafting the contract. Consider the drafter of a consumer contract 
and suppose that this agent is perfectly rational. The rationality assumption has two implications: first the agent is able to anticipate accurately the qualification of contract terms (whether they will be considered abusive by the courts or not); second, the agent can also anticipate exactly all the consequences of a term being qualified as abusive.

Let us then denote:

- A: the lawful behavior of the drafter of the contract. In this event, the drafter offers contracts devoid of unfair terms;

$-\bar{A}$ : the unlawful behavior of the agent. We consider that the drafter voluntarily inserts unfair terms in the contract;

- $G$ : the gain resulting from a contract devoid of unfair terms;

$-\bar{G}$ : the gain resulting from a contract containing at least one unfair term. The issue of the deterrent effect of liability law is only relevant if $\bar{G}>G$. In the opposite case, the professional party has no incentive to break the law. Hence, we focus on the case when $\bar{G}>G$.

$-\bar{G}-G$ : thus represents the additional gain induced by the presence of unfair terms in the contract;

$-p$ : the probability that the drafter of the contract will undergo punishment in the event that he violates the law. We consider that if a suit is filed and the contract does contain an unfair clause, the drafter will be punished. In other words, we do not allow for judicial errors in the model. This assumption is consistent with the existence of lists defining precisely unfair terms and of the Commission des Clauses Abusives, which can be consulted by the judge prior to issuing the judicial decision. Moreover, we also assume that the consumer will only file a suit if the contract actually does contain an unfair clause. In other words, the model does not allow for judicial errors, either of type 1 or 2 . Therefore, the probability $p$ captures at the same time the probability that the consumer will file a claim against the professional party; and the probability that the latter will undergo punishment.

$-S$ : the amount of the compensation inflicted on the drafter of the contract. The amount $S$ aims at repairing the prejudice caused to the consumer.

$-F$ : the civil penalty that can be inflicted upon the drafter of the contract. $^{26}$

$-q$ : the probability that the court inflicts a civil penalty $F$ to the professional party, given that a suit has already been filed.

$-N$ : the number of identical contracts signed by the professional party (i.e. the drafter of the contract);

$-C_{A}$ : the cost of drafting a contract incurred by the party who abides by the law (i.e. who behaves according to $A$ ).

$-C_{\bar{A}}$ : the cost incurred by the drafter in the event that he adopts an unlawful behavior $\bar{A}$

Note that the cost of drafting the contract $\left(C_{A}\right.$ or $\left.C_{\bar{A}}\right)$ is only incurred once, regardless of the number of contracts signed. This assumption is consistent

26. Recall that article L.241-2 of the Consumer Code allows for such a civil penalty as explained above in sections 3.1. This amount is bounded, as mentioned in section 3.3.1. 
with the fact that the professional party signs numerous identical contracts. We further assume that drafting a lawful contract implies additional costs compared to drafting an unlawful contract $\left(C_{A} \geq C_{\bar{A}}\right)$. Not only does the drafter incur informational costs (collecting information about the law and its interpretation by the courts) but he must also be particularly cautious about the terms he inserts in his contract. In practical terms, drafting a lawful contract might require to hire a legal advisor or attorney.

Note that the model does not incorporate explicitly litigation costs. Two alternative interpretations are offered: first, one can argue that if contract law does not act as an efficient deterrent in the absence of litigation costs, the same conclusion remains valid, even more so, when the implementation of the legal rule is hindered by such costs. Second, one can consider that the probability $p$ of a suit being filed decreases as litigation costs rise. The probability $p$ would increase considerably in a judicial system allowing class actions, which is not the case in French consumer law. It is also worth noting that the model does not allow for an out-of-court settlement.

Finally, the model rests on the assumption that the consumer does not notice ex ante the abusive terms. In other words, the consumer does not read - or understand - the contracts and does not compare different options in order to find a contract devoid of unfair terms. Recall that consumer contracts are contracts of adhesion, which implies, as Kessler [1943] points out, a strong asymmetry between the parties. According to Kessler [1943], contractual terms, "are often understood only in a vague way, if at all" by the consumer. In line with this observation, we consider that consumer contracts are characterised by a strong asymmetry, not only in terms of bargaining power but also in terms of financial stakes: the amounts at stake are generally low for the consumer, who therefore does not have incentives to invest in reading and choosing a contract. As explained by Korobkin [2003], consumers only pay attention to the most salient provisions. This analysis has since been confirmed, namely by Ben-Shahar and Schneider [2014] in their book entitled "More Than You Wanted to Know: The Failure of Mandated Disclosure".

Conversely, the professional party signs numerous contracts, such as he has incentives to invest in drafting profit-maximizing clauses. This asymmetry allows the professional party to insert unfair terms.

\subsubsection{Solving the model}

Under these conditions, the drafter of the contract chooses to adopt a lawful or an unlawful behavior, respectively denoted $A$ and $\bar{A}$. His decision trivially depends on the expected value of the gains and losses associated with each scenario. Let us first focus on the case when the court does not impose a civil penalty upon the professional party. As mentioned above, this situation is most frequent in French jurisprudence. The expected gain provided by a contract devoid of unfair terms is equal to $G-C_{A}$. The expected gain provided by a contract containing an unfair term is equal to $(1-p)$ $\left(\bar{G}-C_{\bar{A}}\right)+p\left(\bar{G}-C_{\bar{A}}-S\right)$. 
A rational agent therefore decides to draft a lawful contract if the following condition is verified:

$$
(\bar{G}-G)-\left(C_{\bar{A}}-C_{A}\right) \leq p S
$$

The previous equation is true if the drafter signs one sole contract. Standard form contracts however are signed with numerous parties. Recall that we denoted $N$ the number of identical contracts signed by the professional party. Whence, it is easy to show that the previous equation leads to:

$$
N(\bar{G}-G)-\left(C_{\bar{A}}-C_{A}\right) \leq p N S
$$

The behavior of the agent thus depends on three parameters: the amount of the punishment; the probability of this punishment actually being inflicted upon the drafter of the contract; and the expected increase in profit ensuing from the forbidden action. With this basic framework in mind, let us now tackle the core issue of this article: does French consumer law have a deterrent effect on the drafter with regards to unfair contract terms? We claim that the answer is negative and justify this assertion in the following paragraphs.

\subsection{Main result: the lack of deterrent effect of the French law regarding unfair contract term}

A simple deterrence condition can be deduced from the model presented above in the absence of a civil penalty (section 4.2.1). We then turn to the case when a civil penalty can be inflicted upon the professional party (4.2.2). The results are discussed and compared in section 4.2.3.

\subsubsection{Specifying a deterrence condition in the absence of a civil penalty}

Remember that an unfair term in a consumer contract has two consequences if the consumer goes to court: to start with, the term will produce no effect, as it is considered never to have been written; secondly the drafter could be sentenced to compensate for the prejudice caused to his co-contracting party, in the event that the latter files a claim. In the case of consumer contracts, we can reasonably consider that the damage is only financial. Indeed, unfair contract terms rarely result in moral or physical damage. The damage simply corresponds to a transfer of money from one party to the other in violation of the law, thus generating a transfer of surplus from the consumer to the professional party. Formally, the prejudice caused to the consumer is roughly equal to $\bar{G}-G$, since we consider that unfair terms result in a transfer of surplus. 
According to the principle of equivalence between damages and compensation, the amount of the punishment $S$ will also be equal - or close - to $\bar{G}-G$. Hence, $S \equiv \bar{G}-G$. Inequality (2) is then equivalent to:

$$
\left[\frac{C_{A}-C_{\bar{A}}}{N}\right] \leq(p-1)(\bar{G}-G)^{27}
$$

- On the left-hand side, the member is strictly positive, since we assumed that the costs of drafting a legal contract were more important than those of writing a contract containing unfair terms.

- On the right-hand side, the member is strictly negative.

In other words, the deterrent condition presented in equation 3 can never be verified under the assumptions we presented above. Let us now turn to the case when a civil penalty may be inflicted upon the professional party.

\subsubsection{Incorporating the civil penalty in the model}

Recall that we denote $F$ the amount of the civil penalty inflicted upon the professional party. The incorporation of this new parameter results in a different deterrence condition. The expected gain provided by a contract devoid of unfair terms remains unchanged and is equal to $G-C_{A}$. The expected gain provided by a contract containing an unfair term however is now equal to $(1-p)\left(\bar{G}-C_{\bar{A}}\right)+p\left(\bar{G}-C_{\bar{A}}-S-q F\right)$. The parameter $q$ represents the probability that the court actually inflicts a civil penalty to the drafter of the contract. As mentioned above such penalties are rare in French jurisprudence, which is why we add the parameter $q<1$ to the model. Let $N$ denote the number of contracts signed by the professional party.

In this framework, a rational agent decides to draft a lawful contract if the following condition is verified: $N G-C_{A} \geq(1-p)\left(N \bar{G}-C_{\bar{A}}\right)+p\left(N \bar{G}-C_{\bar{A}}-N\right.$ $(S+q F))$. The previous condition is equivalent to:

$$
\left[\frac{C_{A}-C_{\bar{A}}}{N}\right] \leq(p-1)(\bar{G}-G)+p q F
$$

- On the left-hand side, the member is strictly positive, as explained above in section 4.2.1.

- On the right-hand side, the member can be positive if $p q F$ is sufficiently large.

With this in mind, let us know analyze equations (3) and (4), in order to assess the deterrent effect of French consumer law.

\subsubsection{Analysis}

First, inequality (3) can never be verified in our framework. This result stems from the assumption that $S \equiv \bar{G}-G$. In other words, we show that if

27. Note that the result remains valid if the costs of drafting the contract depend positively on the number of contracts, as long as inserting an abusive clause entails additional costs $\left(C_{A}>C_{\bar{A}}\right)$. 
the amount of punishment is strictly equal to the gain resulting from breaching the law, the drafter of the contract has no incentive to abide by the law. The intuition is that, given the probability $p \leq 1$ of a suit being filed and the fact that damages equal harm, the expected gain of breaching the law is always strictly higher than that of respecting legal requirements.

This observation is consistent with the conclusions drawn by Polinsky and Shavell [2007]: "If injurers who ought to be found liable for harm $h$ are in fact only found liable and made to pay damages with probability $q$, then if damages are raised to $(1 / q) h$, injurers expected liability will be $h$. Thus, the more likely a party is to escape liability, the higher should be damages when the party is found liable. Accordingly, a firm that dumps toxic wastes at night, or an individual who tries to conceal a bad act, should have to pay punitive damages, but not an injurer who causes harm in a noticeable way". The following question naturally comes to mind: what punishment would create good incentives for the contract drafter?

Inequality (4) provides a compelling answer. The drafter of the contract has an incentive to avoid unfair terms if $p, q$ and $F$ are sufficiently large compared to the expected gain of breaching the law $(\bar{G}-G)$. One sees at first glance in equation (4) that several parameters determine the firm's incentive to respect or infringe the law:

- First, as the additional gain resulting from an illegal contract ( $\bar{G}-G$ ) increases, the incentive to violate the law also increases. This observation is very intuitive.

- Second, as the probability $p$ increases, the condition in equation (4) becomes less restrictive. In other words, if consumers are more likely to file a claim in court, the drafter has stronger incentives to abide by the law. So far, this observation is consistent with previous literature, namely Polinsky and Shavell [2007]. The specific feature of consumer contracts is that the financial stakes are often very low for the consumer, whereas they are quite important for the professional since the latter signs numerous identical contracts. Given that the financial stakes are negligible, consumers are not very likely to file a claim (formally, the probability $p$ is small). In order for the legal rule to act as an efficient deterrent, the amount of punishment $F$ should compensate for the low probability of a case being brought to court.

- This observation brings us to the third parameter which determines the firm's incentive to respect the law increases, namely $F$ the amount of the civil penalty. One understands intuitively that the deterrent effect of the law is stronger when $F$ is larger. Equation (4) can be rewritten:

$$
p q F \geq(1-p)(\bar{G}-G)+\left[\frac{C_{A}-C_{\bar{A}}}{N}\right]
$$

The latter equation can be interpreted as follows: if the maximum amount of civil penalty allowed by the law is to low, given the probability of a sanction actually being inflicted $(p q)$ and given the expected gain of violating the law $(\bar{G}-G)$, then the deterrence condition can never be verified. We argue that such might be the case in French law. Recall that according to article L.241-2 of the Consumer Code, the civil penalty is limited to $\mathbf{3 0 0 0}$ 
euros for a natural person and to 15000 euros for a legal entity. Considering the low probability of consumers filing a suit, as explained above, caping the amount of the civil penalty reduces the deterrent effect of the legal rule and does not seem like a relevant policy.

- Moreover, once a suit has been filed, the probability that a sanction will actually be inflicted upon the professional party depends on the how courts use the opportunity they are offered by the Consumer Code. In France, civil penalties are rarely used because courts remain attached to the rule of equivalence between compensation and damages. Hence, $q$ is low, which contributes to the lack of efficiency of the legal rule.

- Finally, it is worth noting that the number of contracts signed by the professional party also has an effect on the deterrence condition. Let us write equation (4) as follows:

$$
N(\bar{G}-G)(p-1)+p q N F \geq C_{A}-C_{\bar{A}}
$$

The parameter $N$ exerts two opposite forces on the firm's incentive to abide by the law:

- On the one hand, $N(\bar{G}-G)(p-1)$ decreases as $N$ increase, since the term is negative. This renders the condition more restrictive. The interpretation is that when the number of contracts increases, the firm's total gain resulting from law infringement also increases. Hence, the firm has a stronger incentive to violate the law.

- On the other hand, $p q N F$ increases with $N$, which renders the condition less restrictive. This effect is due to the fact that when $N$ increases, the probability that one consumer, among all of those who signed a contract, files a suit, $p N$, also increases. Hence, the incentive to violate the law decreases with $N$. This second effect prevails, as one can see in equation (4).

To conclude, the model shows that French liability law, namely the rule of "réparation intégrale du préjudice" renders the prohibition of abusive contract terms in consumer contract poorly effective. Moral and social attachment to some deep-rooted principles in civil law entails considerable social costs. The issue is then to determine up to what amount the social cost borne by the collectivity is reasonable, and when, on the contrary, it becomes excessive and justifies making an exception to the rule. We believe that in the context of consumer contract, it is fully justified to bend the rule of equality between damages and compensation.

\section{Increasing the deterrent effect of French consumer law through punitive damages}

While several arguments are put forward by the opponents of punitive damages, we argue that none are convincing (section 5.1) and that there are 
solid grounds for the admission of punitive damages, particularly in consumer law (section 5.2).

\subsection{Unconvincing arguments against punitive damages}

As explained above, the rule of full compensation essentially originates from case-law and does not rest on any textual foundation. Hence, the question that comes to mind consists in defining the strong attachment to the rule of full compensation, and its corollary, the prohibition of punitive damages.

\subsubsection{A dogmatic ethical argument}

First, european scholars and jurists have shown a strong reluctance to punitive damages for moral and ethical reasons. "The rule of full compensation (...) is as much a symbol as it is a rule of substantive law", according to Brun [2015]. ${ }^{28}$ Our contention is that this symbol has a high social cost, which could easily be reduced. The principle according to which one should never be enriched by a judicial proceeding is deeply-rooted in French minds. Yet, as suggest Viney and Jourdain [2006], this rules obliterates some other criteria that should be taken into consideration to allocate damages: the behavior of the debtor, the gravity of his fault, his capacity to pay for damages, as well as the victim's financial situation. We will see in the following section that the case of unfair contract terms offers a blatant example of the perverse consequences which result from a systematic enforcement of this rule.

The rule of full compensation has no other foundation than the moral intuition according to which being enriched through a legal procedure seems somehow reprehensible. While the rule seems sensible under some circumstances, it is no longer efficient in the presence of standard form contracts. This moral concern should not stand in the way of implementing a more efficient punishment when necessary. By refusing a more general use of punitive damages, the legislator and judges implicitly tolerate a deliberate violation of the law in the perspective of a financial gain. In other words the issue is not whether or not enrichment through a trial is morally reprehensible, but rather whether it is more so than a deliberate lucrative violation of the law. When framed in that manner, the ethical argument against punitive damages appear very weak.

\footnotetext{
28. Translation by the author. The original text is taken from Brun [2015]: "Le principe de réparation intégrale est au droit de la responsabilité civile ce que le principe de la force obligatoire de l'article 1134 du Code Civil est au droit des contrats: un symbole autant qu'une norme opératoire."
} 


\subsubsection{A contestable argument based on the need for legal certainty}

A second argument that can be put forward against punitive damages is that they would lead to legal uncertainty. The rule of full compensation implies a high degree of legal certainty, to the extent that the injurer or the contractor is able to anticipate the amount of damages.

This argument can easily be dismissed. First, one can argue that the drafter of the contract can bear the risk of such legal uncertainty. It seems sensible that the party responsible for the content of the contract should be required to take the necessary measures to ensure that he abides by the law.

Second and foremost, legal uncertainty can be limited by providing some guidelines for the allocation of punitive damages. In countries where punitive damages are used, judges follow such guidelines. For example, the Supreme Court of the United States limited punitive damages in the case BMW of North America, Inc. v. Gore. ${ }^{29}$ In the name of the Due Process Clause of the Fourteenth Amendment, the Supreme Court decided that excessively high punitive damages could be considered unconstitutional. Punitive damages are considered to be excessive if they exceed what is necessary to ensure efficient deterrence. Three conditions are used by the Supreme Court to make this assessment: first, the degree of reprehensibility of the defendant's conduct; second the ratio of the compensatory damages awarded (actual or potential harm inflicted on the plaintiff); and finally, a comparison between the punitive damages awarded and civil or criminal penalties that could be imposed for comparable misconduct. The example of American law illustrates that punitive damages do not necessarily lead to a greater legal uncertainty.

\subsection{Towards the slow acceptance of punitive damages in French law}

There is a clear tendency among scholars to be increasingly favorable to punitive damages (section 5.2.1). This tendency has slowly found a timid echo in French jurisprudence, which has lately been less hostile to such damages (section 5.2.2), but has not yet been sufficiently acknowledged by the legislator (section 5.2.3).

\subsubsection{A clear tendency among scholars}

Liability law is still mainly considered by French legal scholars to fulfill one task only: guarantee the compensation of damages. While an increasing

29. BMW of North America, Inc. v. Gore, 517 U.S. 559 (1996).

REP 129 (2) mars-avril 2019 
number of scholars insist on the prevention role of liability law (see for instance Fabre-Magnan [2007]), their impact on jurisprudence and positive law is surprisingly insignificant.

Among the first scholars to highlight the deterrent effect of liability law is Starck [1947], whose seminal work on the "double function of civil liability" needs to be mentioned. In his thesis, Boris Starck argues that civil liability serves a double purpose: it is not only a means of compensation, but also operates as a punishment and deterrent. To defend this controversial idea, Boris Starck uses the notion of "lucrative faults". In fact, he is the first French scholar to offer a definition of "lucrative faults" in his handbook (Starck et al. [1996]): according to Boris Stark, a lucrative fault refers to any "fault that, in spite of the compensatory damages that its author will be condemned to pay, leaves him with a positive gain, such that he has no reason not to engage in the illegal behavior."

The concept of lucrative fault as defined by Starck [1947] more or less coincides with what economists call opportunism. It is quite striking that this definition perfectly describes the behavior of the drafter of the contract we have studied above. Indeed consumer law seems to be a privileged field for lucrative faults because of the considerable imbalance between the expected gains and risks. In the field of consumer law, some authors have underlined the specific need for punitive damages, as the risk of opportunism is particularly widespread. The most influential is without a doubt Jean CalaisAuloy (see for instance Calais-Auloy [1985]), whose voice in favor of punitive damages still echoes to this day.

More recently, Mesa [2006] tackled the issue of lucrative faults in civil law. The author argues that French law does not sufficiently take into account some exceedingly reprehensible behaviors and considers that several alternative rules could serve as an efficient deterrent, namely class actions and/or punitive damages. In the same line of thought, Vingiano-Viricel [2017] argues that the notion of faute lucrative deserves to be translated into positive law. The author regrets that the reform of the French Civil Code of 2017 did not incorporate the concept of lucrative fault into the Code and insists on its importance to overcome the deficiencies of the rule of full compensation.

It is worth noting that the economic analysis has long been favorable to punitive damages or analogous systems which increase the deterrent effect of the legal rule. Our conclusions are first consistent with Polinsky and Shavell [1998 and 2007], as explained in section 4.2.1. We apply their conclusion, according to which the magnitude of the fine should increase when the probability of the sanction decreases, to the specific case of consumer contracts. Recall that one of the key features of consumer contracts is that the financial stakes for consumers are low. Hence, the probability of a suit being files is also low. Therefore, we argue that the conclusions drawn by Polinsky and Shavell [1998 and 2007] plead in favor of a high fine in the case of consumer contracts. In practical terms, caping the amount of the civil penalty that might be inflicted on the professional party appears to be inefficient in terms of deterrence.

Our conclusions are also consistent with Polinsky and Che [1991]. These authors show that there always exists a decoupled system of liability which leads to lower social costs than a coupled liability rule. In their model, the 
decoupled system presents two advantages: avoiding frivolous suits from the plaintiffs and increasing the level of care ex ant of the defendant. In our framework, we focus solely on the second aspect. Indeed, frivolous suits are not a concern to the extent that consumers do not have incentive to file a claim, as explained above. Applying the logic developed by Polinsky and Che [1991] to consumer contracts makes a strong argument in favor of punitive damages: increasing the payment by the defendant (the professional party) increases his incentive to exercise care (that is to say to invest in drafting a legal contract rather than inserting abusive terms).

\subsubsection{A timid progress in jurisprudence}

The previous arguments have very slowly and timidly had some influence on French case law. First and foremost, the Conseil Constitutionnel ${ }^{30}$ does not consider the rule of full compensation to have constitutional value. The French Constitutional Court precociously avoids to mention the amount of compensation that should be attributed to a victim to repair a prejudice. French scholars unanimously consider that this implies that the amount of damages is not subject to any constitutional rule. ${ }^{31}$ It follows that punitive damages are not unconstitutional. In other words, no supra-legal rule or principle stands in the way of introducing punitive damages in French law.

In line with the previous argument, the French Supreme Court ruled in 2010 that punitive damages were not per se contrary to public order. ${ }^{32}$ In this noteworthy decision, the Cour de Cassation had to decide upon the exequatur in France of an American ruling in which the defendant was condemned to paying important punitive damages. The Court ruled that while punitive damages were not as such contrary to public order rules, they were in that specific case excessive. This decision is noticeable as it is the first time that the French Supreme Court explicitly states that punitive damages are not intrinsically contrary to any legal rule of public order.

To conclude, there is no legal or constitutional rule in the French legal system that would not be compatible with punitive damages.

\subsubsection{The inertia of the legislator}

The widening gap between the increasing number of scholars who argue in favor of punitive damages and the tendency in case law on one side; and the outstanding inertia of the legislator on the other side is quite bewildering. Acknowledging this deficiency, several scholars proposed to allow punitive damages in French law. The most noteworthy example is the reform

30. The Conseil Constitutionnel is the French constitutional court.

31. See for instance Molfessis [1997]; Viney and Jourdain [2001]; and Brun [2005].

32. Cass. Civ. 1 civ. 1 st december 2010, decision n 09-13.303. 
project Catala 33 which was favorable to punitive damages. Article 1371 of the Catala project explicitly referred to the notion of lucrative fault: "the author of a fault which is obviously deliberate, particularly in the case of a lucrative fault, can be condemned to punitive damages, part of which can be allocated to the State. The decision to allocate punitive damages must be specially motivated". Hence, a special motivation is mandatory and the judge is required to make a clear distinction between punitive damages on one side, and compensatory damages on the other side. ${ }^{34}$ Similarly, a law project issued in July 2010 pleads in favor of punitive damages. ${ }^{35}$ In this project proposed by Senator Laurent Béteille, it was provided that the amount of punitive damages would be limited to twice the amount of compensatory damages.

In spite of several attempts, punitive damages have not been integrated in French law. The major reform of French civil law carried out in April 2016 remains faithful to the rule of strict equivalence of prejudice and damages. While punitive damages were mentioned in several reform projects, they have not been adopted by the legislator. In March 2017, the Minister of Justice presented a new reform project of civil liability. ${ }^{36}$ The project provides that punitive damages can be awarded in the case of non-contractual liability under certain conditions and limits. For instance, the amount of damages could not exceed ten times the profit ensuing from the unlawful behavior. While this project undoubtedly constitutes a progress and paves the way for the admission of punitive damages in French law, one can only regret that such damages are constrained to non-contractual liability.

This brief overview confirms that punitive damages are a contentious issue: while many reports and projects explicitly argue in favor of punitive damages, the French legislator remains reluctant to admit such damages. Our contention is that the main impediment to the introduction of punitive damages in the French judicial system is the deep-rooted idea that liability law should remain a mere means of compensation and in no event serve as a deterrent of socially undesirable behavior. This rule has no solid justification in the presence of lucrative faults.

\footnotetext{
33. The "Avant projet de réforme du droit des obligations et du droit de la prescription" is a major project finalized in 2005 , which aimed at reforming the French Civil Code, in particular the articles concerning contracts, quasi-contracts, civil liability and prescription. Only the part of the project pertaining to prescription has actually led to a reform in 2008 . The commission was composed of numerous law scholars and several judges appointed by the Minister of Justice and directed by Pierre Catala.

34. Translation by the author. Article 1371 of the project Catala states in its original version: L'auteur d'une faute manifestement délibérée, et notamment d'une faute lucrative, peut être condamné outre les dommages et intérêts compensatoires, à des dommages et intérêts punitifs dont le juge a la faculté de faire bénéficier pour une part le Trésor public. La décision du juge d'octroyer de tels dommages et intérêts doit être spécialement motivée et leur montant distingué de celui des autres dommages et intérêts accordés à la victime. Les dommages intérêts punitifs ne sont pas assurables.

35. Proposition n 657 of 9 July 2010.

36. http://www.justice.gouv.fr/publication/

Projet_de_reforme_de_la_responsabilite_civile_13032017.pdf
} 


\section{Conclusion}

This article studies the deterrent effect of French consumer law by focusing more specifically on the prohibition of abusive contract terms. We argue that in the particular case of abusive contract terms, the law does not serve as en efficient deterrent. The reason thereof is simply that the expected value of the gains resulting from an unlawful behavior clearly exceeds the amount of the anticipated punishment. In other words, inserting an unfair term in a contract constitutes a lucrative fault. The case of unfair terms in consumer contract is quite convincing, as it is extremely persuasive and highlights unambiguously the lack of deterrence effect. However our intention is to use this case as a mere illustration of a more general phenomenon: our claim is that this lack of deterrent effect is not only due to an isolated legislative void, but is linked to the structural foundations of French liability law.

Indeed French liability law is not conceived as an incentive mechanism but as a mere compensation tool. Although an increasing number of scholars formally acknowledge the preventive effect of liability law, this remains a marginal approach with no significant effect on positive law. As no convincing judicial argument justifies constraining liability law to its compensatory purpose, we believe that the main barrier to admitting more widely this preventive role is cultural. Our contention is that the main impediment to the introduction of punitive damages in the French judicial system is the deeprooted idea that liability law should remain a mere means of compensation and in no event serve as a punishment or deterrent device. We argue that this rule of strict equivalence between damages and compensation is not justified in the case of lucrative faults. Hence, the rule of strict equivalence between damages and compensation offers a blatant example of the cultural impediment that stands in the way of a necessary reform. As for how precisely punitive damages should be implemented in the French legal system, this issue is left for future research.

\section{References}

BECKER G. [1968], Crime and punishment: An economic approach, Journal of Political Economy 76(2), 169-217.

BEHR V. [2005], Punitive damages in america and german law - tendencies towards approximation of apparently irreconcilable concepts, Chicago Kent Law Review 78, 105-161.

BEN-SHAHAR O. and SCHNEIDER C. [2014], More Than You Wanted to Know: The Failure of Mandated Disclosure, Princeton University Press.

BERNARDO A., TALLY E. and WELCH I. [2000], A theory of legal presumptions, Journal of Law, Economics and Organization 16(1), 1-49. 
BRUN P. [2005], Responsabilité civile extracontractuelle, 4 edn, Litec.

BRUN P. [2015], Responsabilité du fait personnel, in "Répertoire Dalloz", Dalloz.

CADIET L. [2000], Sur les faits et les méfaits de l'idéologie de la réparation, in "Le juge entre deux millénaires. Mélanges offerts à Pierre Drai", Dalloz, p. 495-510.

CALAIS-AULOY J. [1985], Propositions pour un nouveau droit de la consommation, Documentation Française.

CALAIS-AULOY J. and STEINMETZ F. [2003], Droit de la consommation, 3 edn, Dalloz.

CHRISTIE G. [1991], Current trends in the american law of punitive damages, AngloAmerican Law Review 20, 349-370.

FABRE-MAGNAN M. [2007], Droit des obligations Tome 2 : Responsabilité civile et quasi-contrats, PUF.

FLUET C. and DEMOUGIN D. [2005], Deterrence versus judicial error: A comparative view of standards of proof, Journal of Institutional and Theoretical Economics 161(2), 193-206.

FLUET C. and DEMOUGIN D. [2008], Rules of proof, courts and incentives, The RAND Journal of Economics 39(1), 20-40.

GAUDEMET-TALLON H. [2011], De la conformité des dommages et intérêts punitifs à l'ordre public, Revue critique de droit international privé p. 93.

GOYDER M. and BROOKER S. [2007], Warning: Too Much Information Can Harm, Final report, Better Regulation Executive and National Consumer Council.

GREENLEAF S. [1963], A treatise on the law of evidence, Boston, Little, Brown.

INNES R. [1999], Optimal liability with stochastic harms, judgement-proof injurers, and asymmetric information, International Review of Law and Economics 19, 181-203.

KESSLER F. [1943], Contracts of adhesion, some thoughts about freedom of contract, Columbia Law Review 43, 629-632.

KOROBKIN R. [2003], Bounded rationality, standard form contracts, and unconscionability, The University of Chicago Law Review 70(4), 1203-1295.

LAITHIER Y.-M. [2008], Clause pénale et dommages et intérêts incitatifs, in C. Jamin, ed., Droit et Économie des Contrats, L.G.D.J.

LE TOURNEAU P. [2011], Droit de la responsabilité et des contrats, Dalloz Action, Dalloz.

LEVENEUR L. [2009], Études offertes à la mémoire du Professeur Bruno Oppetit, Litec, chapter Les recommandations de la Commission des clauses abusives.

LEWIS T. and SAPPINGTON D. [1999], Using decoupling and deep pockets to mitigate judgment-proof problems, International Review of Law and Economics 19, 275-293.

MALAURIE P. [2004], L'effet prophylactique du droit civil, in "Études du droit de la consommation: liber amicorum Jean Calais-Auloy de droit de la consommation, Liber amicorum", Dalloz, p. 669.

MESA R. [2006], Les fautes lucratives en droit privé, PhD thesis, Université du Littoral.

MOLFESSIS N. [1997], Le Conseil constitutionnel et le droit privé, L.G.D.J.

POLINSKY A. M. and CHE Y.-K. [1991], Decoupling liability: optimal incentives for care and litigation, RAND Journal of Economics 22(4), 562-570. 
POLINSKY A. M. and SHAVELL S. [1979], The optimal tradeoff between the probabilitiy and magnitude of fines, American economic review 69(5), 880-891.

POLINSKY A. M. and SHAVELL S. [1998], Punitive damages: an economic analysis, Harvard Law Review 111(4), 869-862.

POLINSKY A. M. and SHAVELL S., eds [2007], Handbook of Law and Economics, Vol. 1, Elsevier.

POSNER R. [1987], The law and economics movement, American economic review 77(2), 1-13.

SEDGWICK T. [1894], A treatise on the measure of damages, New York, Baker, Voorhis and CO.

SINTEZ C. [2014], La sanction préventive en droit de la responsabilité civile, Dalloz.

STARCK B. [1947], Essai d'une théorie générale de la responsabilité civile considérée en sa double fonction de garantie et de peine privée, $\mathrm{PhD}$ thesis, Paris II.

STARCK B., BOYER L. and ROLAND H. [1996], Obligations, 1. Responsabilité délictuelle,5 edn, Litec.

TUNC A. [1975], Responsabilité civile et dissuasion des comportements antisociaux, in "Aspects nouveaux de la pensée juridique: recueil en hommage à Marc Ancel ", vol. I, Pédone, p. 407-4015.

VINEY G. and JOURDAIN P. [2001], Traité de droit civil ; Les effets de la responsabilité, 2 edn, L.G.D.J.

VINEY G. and JOURDAIN P. [2006], Traité de droit civil ; Les conditions de la responsabilité, 3 edn, L.G.D.J.

VINGIANO-VIRICEL I. [2017], "La faute lucrative: une notion en construction en droit français ", Revue Trimestrielle de Droit Commercial p. 19-25. 